\title{
Linking Change Initiatives: The Carnegie Academy for the Scholarship of Teaching and Learning in the Company of Other National Projects
}

\section{Barbara Cambridge}

American Association for Higher Education

The scholarship of teaching and learning provides an overarching framework for progress on a number of important educational issues today. The Carnegie Academy for the Scholarship of Teaching and Learning encourages connections with other national projects that deal with issues such as defining student learning outcomes, building an infrastructure of support, and establishing evidence for purposes of accountability in mutually supportive ways. Connecting such efforts bonors faculty time in the midst of multiple demands and raises the likelihood of significant, lasting impact on the quality of teaching and learning.

\section{INTRODUCTION}

O n many vibrant campuses, change efforts can exceed energy levels. Faculty members with real commitments to student learning are exploring a variety of approaches, taking up writing across the curriculum, learning to assess critical thinking, implementing technology in their teaching, incorporating students in their research, representing student work in program reviews, explaining to legislators the need for developmental courses, refining assignments for collaborative learning groups, 
and on and on. Sometimes faculty members have to say, "I can't do anything more right now. I just don't have the time."

Time is the most precious resource for faculty members. If a faculty member decides to dedicate effort to a particular project, then it is important that the results of that project be used in as many ways as possible. For example, if a faculty member adopts student portfolios as a learning and assessing tool, the time invested in development and implementation will be better spent if the portfolios contribute to assessing student progress, representing the university in accreditation, and providing a basis for curricular changes.

This call for multiple uses of initiatives, however, is not a call for easily finished tasks. For example, scholars of teaching and learning explore the intellectual problems that emerge during the process by which novices and experts learn in their disciplines. These problems are not things to be solved and done away with. They are, as Randy Bass puts it, the kind of problems at

the heart of the investigative process.... Changing the status of the problem in teaching from terminal remediation to ongoing investigation is precisely what the movement for a scholarship of teaching is all about. $(1999$, p. 1)

Ultimately, the measure of success for the scholarship of teaching movement will not be the degree to which I can-by focusing on the "many layers of practice" at the heart of teaching-discover solutions worth implementing, but the extent to which it is successful in discovering problems worth pursuing. (1999, pp. 8-9)

In other words, Bass contends that really intriguing problems in teaching and learning will necessarily and interestingly take time to investigate. During that time, faculty members will undoubtedly be engaged in other work as well, work that has potential to be consonant with this ongoing scholarly work in teaching and learning if we look for productive connections and interactions.

For the 2001 American Association for Higher Education (AAHE) National Conference on Higher Education, Pat Hutchings, Senior Scholar at the Carnegie Foundation for the Scholarship of Teaching and Learning (CASTL), and I examined a set of national projects involving learning and teaching (Hutchings \& Cambridge, 2001). We looked for productive connections between the work of individual scholars, cam- 
puses, and disciplinary associations in CASTL and the work of other national initiatives. Earlier, we had noticed that many campuses had affirmed that their participation in the Campus Program, one of three activities of the higher education program at the Carnegie Foundation for the Advancement of Teaching, had given them an occasion to link across their campus multiple and disparate efforts to improve teaching and to make it more scholarly. Unlinked pockets of activity had resulted in duplicative or, at the least, nonmutually supportive efforts. Faculty members felt pulled in many directions, and administrators worried about effective uses of resources. The Campus Program offered a way to link programs promoting scholarly teaching for the purpose of setting campus conditions for supporting the scholarship of teaching and learning. Campuses that had begun to value or who valued scholarly teaching saw the opportunity to take a next step by bringing their projects together to set conditions necessary for supporting faculty who do or want to do the scholarship of teaching and learning, and for institutional approaches to change that in themselves can be scholarly work.

An array of national programs also offers productive links for work on the scholarship of teaching and learning. Three categories of programs focus on defining student learning outcomes, building an infrastructure of support, and establishing evidence for purposes of accountability. Describing these categories in this chapter, I will include a total of 15 examples, often using language with which the program defines itself and well aware that you will be able to name other projects that could be on the list. This set of projects is meant as a heuristic to prompt thinking about ways to be explicit about the multiple uses of the processes and outcomes of work in these important initiatives.

\section{Defining Student Learning Outcomes}

Individual campuses, cohorts of campuses by institutional type or common interests, and disciplinary groups are all doing the hard work of identifying appropriate student learning outcomes for degree programs, preparation for citizenship or the work place, or preparation in majors. Five national projects illustrate the power of groups working together to accomplish these tasks.

Greater Expectations, an initiative of the Association of American Colleges and Universities (AAC\&U), has convened a panel of leaders in education, government, business, and community action to develop a statement of aims and purposes for 21 st-century college-level study. The 
panel will articulate and disseminate liberal learning outcomes that should emerge from a college education. A set of selected campuses is identifying best practices and assisting through their experience other campuses wanting to achieve these outcomes with students. (http:// www.aacu-edu.org)

The League for Innovation in the Community College also has taken on an expansive task related to student learning outcomes. In the 21 stCentury Skills Project, the league is defining what knowledge, skills, and abilities community college students need to be active, contributory 21 st century citizens. After identifying knowledge, skills, and abilities, the project will provide new approaches for certifying learning so that students have more personal information about their learning achievements and so that standards for learning are responsive to requirements of the knowledge age and global economy. Sixteen community colleges are involved in the demonstration phase of this work. (www.league.org)

Twenty-seven other institutions are working together in the Student Learning Outcomes Initiative led by Alverno College. They are creating a framework and examples that identify and illustrate the assumptions, principles, and practices that campuses can use in making student learning the organizing principle of their work. The framework deals with clarity about student outcomes; teaching, learning, and assessing; alignment of structures and resources; and continuous improvement. Not advocating a certain set of outcomes, this project emphasizes the need for each institution to define its outcomes as a precursor to everything else it does. (Tim.Riordan@alvemo.edu)

Two other projects look at disciplinary frameworks in their emphases on outcomes. The National Council on Education and the Disciplines, organized by the Woodrow Wilson National Fellowship Foundation, engages high school and college faculty through their disciplines in developing course sequences for grades 11-14, with attendant standards and assessments. They focus on four core literacies: language arts, history, math/quantitative thinking, and science. The aim is to connect the organizational and political structures that administer $\mathrm{K}-16$ with the disciplinary communities that provide the intellectual content of reform. (www.woodrow.org.nced)

In the Quality in Undergraduate Education (QUE) project as well, the emphasis is on a seamless transfer environment based on what students know and can do. Faculty members from clusters of four- and twoyear colleges are working to develop voluntary discipline-based student learning outcomes in the undergraduate major. Focus disciplines include 
biology, chemistry, English, history, mathematics, and physics. States with participating institutions include California, Georgia, Maryland, and Nevada. (www.gsu.edu/que)

Scholars of teaching and learning often ask the same questions and puzzle about the same problems as faculty members and administrators in these five projects. For example, Mills Kelly, in history at George Mason University, reflects on what doing history means for undergraduate students in beginning history courses. What do they need to know how to do in order to do history? At Miami University, Ted Wagenaar has asked the question of himself and colleagues within the American Sociological Association: "What do sociology majors need to know and be able to do?" In the field of music, Susan Conkling at Eastman School of Music has puzzled about what undergraduates need to undertake to become professional musicians.

Campus Program institutions question, too, the outcomes that they insist on for their students. Augustana College undertook general education reform by, among other activities, studying what others saw as desired outcomes for undergraduates and then determining what was important for their particular students. The University of Michigan has concentrated on investigating through interdisciplinary course development the skills and knowledge important to its students. The first campus-wide work at the University of Georgia after the establishment of its Teaching Academy focused on the first-year experience of students and the senior-year experience, asking questions about how students progress from one to the other and what outcomes they achieve by their senior year.

Faculty members and faculty developers can ask themselves about the relevance of work by faculty members, administrators, and campus groups at a single institution to these national projects. Because many campuses are working on defining, documenting, and assessing student learning outcomes, they may find intersections among projects. Subsequent linking up of people and initiatives can increase the value of the work of each.

\section{BuIlding an Infrastructure of Support}

CASTL's design assumes that change occurs not only with individual effort but also with an institution's commitment to change. Although part of that commitment includes developing policies and practices that support the scholarship of teaching and learning, sustainability demands infrastructure. On the national level, five projects contribute to systemic 
change through attention to faculty preparation, faculty development, and the reward system.

Two projects concentrate on infrastructures that promote curricular and programmatic change to prepare university faculty who have perspective and skills to treat their teaching as a legitimate area for scholarly inquiry. Preparing Future Faculty, a joint project of the Council of Graduate Schools and the Association of American Colleges and Universities, establishes partnerships between colleges and universities to develop and sustain university-wide and departmental programs for doctoral students to cultivate a new generation of faculty members who take teaching seriously as a central part of their work. Recent collaborations between institutions that prepare and institutions that hire faculty have involved a variety of disciplines and disciplinary associations. (http://www.preparingfaculty.org/) (http://www.aacu edu.org/Initiativies/futurefaculty.html)

The Carnegie Foundation for the Advancement of Teaching is also Rethinking the Doctorate in a project with that name. This five-year program of research and collaborative efforts has three components: conceptualizing the common core and the diversity of doctoral programs, especially across disciplines and professions; empirical work with a small number of doctoral programs as they experiment with new forms of education; and treating this work as scholarship of teaching and learning by research and convenings that enable stakeholders to build on one another's work. (www.carnegiefoundation.org)

This scholarly approach of building on one another's work is a hallmark of the Flashlight Program, part of the Teaching, Learning, and Technology Group that is an affiliate of AAHE. Among an array of initiatives is Flashlight Online, which enables investigators to combine their own questions with selected, validated items chosen from the Flashlight Current Student Inventory, administer surveys on line, get analyses from Flashlight, and share studies with others. Training, an online library, and studies conducted for institutions are other initiatives that support the building of infrastructures. (http://www.tltgroup.org/programs/flashlight.html)

A center is one kind of infrastructure created to support efforts at change: The centers for teaching and learning at many institutions stand as examples. But Georgetown University has established a center that serves a national constituency. The Center for New Designs in Learning and Scholarship (CNDLES) generates work on reflective practice, learning technologies, and advanced study in teaching and learning. The latter provides resources for the scholarship of teaching and learning and a 
scholars-in-residence program among other services. (http://www. georgetown.edu/main/provost/candles/)

The final two examples in this series feature national infrastructures addressing the ways in which faculty members are acknowledged for their scholarly work. Establishing a Model Infrastructure to Sustain Communities for Peer Review of Teaching builds on work with course portfolios and peer review to develop a system of peer evaluation for teaching materials viewed as scholarly, intellectual work. Participants from University of Nebraska, Lincoln; Kansas State University; Indiana University, Bloomington; Texas A\&M; and the University of Michigan, Ann Arbor are developing discipline-specific rubrics for assessing portfolios as well as a network of shared expertise. (www.unl.edu/peerrev)

A related project, run by the Samford Center for Problem-Based Learning, is establishing a national network to facilitate national peer review of the design, delivery, and documentation of problem-based learning courses and curricula. Examples of peer-reviewed courses and curricula will be made available in the project's web-based clearinghouse. (www.samford.edu/pbl)

Campuses must decide what kind of infrastructure best fits their own needs in supporting scholarship of teaching and learning on their campus. For example, Texas Tech University has created a Teaching Academy to undertake campus projects. Foothill College created a physical structure to house its Teaching Academy. On the other hand, Buffalo State College determined that an academy, physical or virtual, would not serve its needs as well as a networking among locations of work across the campus. Similarly, Penn State University has established a Teaching and Learning Consortium, made up of a steering committee and teams for planning and evaluation, coordinating, department heads, learning academy faculty, teaching assistants, students, learning support units, and deans. The University of Portland has convened a standing committee from all academic units on campus as well as from a variety of campus committees. At the University of Notre Dame, as on many campuses, the Center for Teaching and Learning coordinates efforts throughout the institution. The vast majority of campuses in the Campus Program have identified a sustaining and sustainable infrastructure supported by senior administration as essential to change in campus culture necessary for establishing the centrality of the scholarship of teaching and learning.

Faculty members and faculty developers can examine the infrastructure on their own campus. They can then compare practices those of fac- 
ulty members and administrators in the five national projects described in this section. They may discover ways to link work in a way that facilitates systemic change.

\section{Establishing Evidence for Purposes of Accountability}

Although most faculty members do scholarly work in teaching and learning to improve student learning and to add to the knowledge base in their disciplines, their work can also contribute evidence for various kinds of accountability. Both state legislatures and accrediting bodies are paying closer and closer attention to the topic with which this piece began: student learning outcomes.

The recent highly publicized Measuring Up 2000: The State-by-State Report Card for Higher Education (National Center for Public Policy and Higher Education, 2000) highlighted in the public eye the dearth of evidence available for grading states in one crucial area: student learning. Although data could be found to judge on the areas of preparation, participation, affordability, completion, and benefits, not one state had enough evidence to rate it on student learning. Because reports will be issued again in at least 2002 and 2004, pressure is on states to generate information that can be used by this kind of measurement.

One recent development that offers hope for legitimate data for the report card, and equally or more importantly for internal improvement, is the National Survey of Student Engagement (NSSE). This national survey of first-year and senior students focuses on their college experiences using research-based indicators of undergraduate quality. The survey provides benchmarking through national norms of educational practices and performance by institutional type, diagnosing by identifying areas where schools can enhance students' educational experiences, and monitoring through documenting institutional improvement over time. Acknowledging that student learning occurs outside as well as inside the classroom, the survey emphasizes what students do with institutional resources in moving toward learning goals. (www.indiana.edu/ nsse@indiana.edu)

A second kind of accountability, applicable to both private and public colleges and universities, is accreditation. Recognizing that student learning has been underemphasized in the past, regional accrediting bodies, as well as many specialized accreditors, are revising their processes and standards to focus much more closely on student learning outcomes. A trailblazer in this accreditation reform is the Western Association of 
Schools and Colleges (WASC), whose new accreditation process focuses on educational effectiveness. Making accreditation more useful to institutions, the process enables an institution to decide in an initial proposal on a focus for accrediting visits and to generate evidence that concentrates not on inputs but on outcomes, especially those of student learning. (www.wascweb.org)

Helping institutions to generate, document, and represent the requisite kinds of evidence for this purpose is one objective of the Urban Universities Portfolio Project. Six universities are creating web-based institutional portfolios to demonstrate effectiveness to various stakeholders, experimenting with new approaches to multiple kinds of institutional evaluation. One consequence of the project for Indiana University-Purdue University Indianapolis (IUPUI) (which cosponsors the project with AAHE), California State University at Sacramento, Georgia State University, Portland State University, the University of Illinois at Chicago, and the University of Massachusetts, Boston has been greater clarity about student learning outcomes and the kinds of evidence warranted by different audiences about progress toward outcomes. (www.imir.iupui. edu/portfolio)

Institutions in the Campus Program are setting the scene for being able to supply valid and reliable evidence of student learning for purposes of accountability. When completion rates are questioned, for instance, Middlesex Community College will be able to state what the motivations of their students are for attending Middlesex and how the faculty are addressing issues of motivation, all because of the college's last two years of scholarly work as a faculty investigating motivation. Attentive to demands for critical thinking skills among graduates, Shawnee State University has created a group of initiatives centered on fostering and assessing critical thinking in the general education program, with one desired outcome being measures for multiple uses. The Center Scholars at the Center for Instructional and Professional Development at the University of Wisconsin, Milwaukee (UWM) have examined issues in teaching and learning that will enable UWM to document its commitment to the learning outcomes outlined in the Milwaukee Plan, the institution's stated mission against which it is judged both by the state and by its accrediting body.

Faculty members and faculty development staff members can identify campus projects that might intersect with these national projects addressing accountability. As a campus decides to undertake collective activities around the scholarship of teaching and learning, it can design 
work that links with both the purpose of improvement and that of accountability.

Faculty development on any campus necessarily has multiple emphases. As faculty development staff members approach faculty members, departments, or schools to undertake a new initiative, they can try to link that new initiative to a current one or to a goal that already has support. The current project or goal might be local, or it might even be national. The currency of being part of a national movement is many times golden.

The Carnegie Academy for the Scholarship of Teaching and Learning itself has added currency to established or emergent campus work. But it, too, benefits from finding links to, supports from, and contributions to other national projects. The line up in this chapter foregrounds a few of many initiatives that find ties to CASTL's work and to the work of campuses that honor the scholarship of teaching and learning.

Honoring the time of faculty members and the objectives of improving what we know about teaching and learning, let's provide links, build bridges, join hands, or use other such metaphors to identify the ways in which we augment and aggregate the good work around the scholarship of teaching and learning going on at both the national and local levels.

\section{REFERENCES}

Bass, R. (1999, February). The scholarship of teaching: What's the problem? Invention: Creative thinking about learning and teaching, 1(1), 1-10.

Hutchings, P., \& Cambridge, B. (2001). The Carnegie Academy for the Scholarship of Teaching and Learning (CASTL). Projects and initiatives that influence the environment for CASTL's work. Paper presented at the Annual Forum on Faculty Roles and Rewards, Tampa, FL.

National Center for Public Policy and Higher Education. (2000). Measuring up 2000: The state-by-state report card for higher education. Washington, DC: Author.

\section{Note}

For more information about the Carnegie Academy for the Advancement of Teaching and Learning, see www.carnegiefoundation.org. For more information about the Campus Program, see www.aahe.org and aahe.ital. utexas.edu. 
Contact:

Barbara Cambridge Vice President for Programs

American Association for Higher Education

One Dupont Circle, Suite 360

Washington, DC 20036

(202) 293-6440, x760

Email: bcambridge@aahe.org

Barbara Cambridge is director of teaching initiatives at the American Association for Higher Education. She is on leave from Indiana University-Purdue University Indianapolis where she is Professor of English and Associate Dean of the Faculties. At AAHE, Cambridge coordinates the Campus Program, one of the three activities of the higher education program at the Carnegie Foundation for the Advancement of Teaching. 